\title{
MODEL OF JUDGES SUPERVISION FOR INDONESIA INDEPENDENT JUDICIAL POWER IMPLEMENTATION ${ }^{\Omega}$
}

\author{
Muhammad Fauzan, Riris Ardhanariswari, and H.A. Komari \\ Faculty of Law of Universitas Jenderal Soedirman \\ E-mail: fauzanhtn@yahoo.co.id; ririsardhana@gmail.com; komari@gmail.com
}

\begin{abstract}
Judges supervision in Indonesia's constitutional system in the future will only be performed by Judicial Commission. Judicial Commission involves Judicial Commission, Provincial Judicial Commission and District/City Judicial Commission based on each authority. The research discusses model of judges supervision to implement an independent judicial power for the future Indonesia. This research is a normative juridical research with statute approach and conceptual approach. The results show Local Judicial Commission has duties and authorities to; First, monitor and surpervise Judges' behavior. Second, receive report from the people related to the violence of Ethic Code and/or Judges Code of Conduct. Third, verify, clarrify, ad investigate report related to presumption of violation of Ethic Code and/or Judges Code of Conduct covertly. Fourth, take legal action and/or other actions to individual, group or legal entity that degrade the honor and dignity of Judges.
\end{abstract}

Keywords: Judicial Commission, judicial power, supervision

\begin{abstract}
Abstrak
Pengawasan hakim dalam sistem ketatanegaraan Indonesia di masa yang akan datang hanya dilakukan oleh Komisi Yudisial. Komisi Yudisial tersebut meliputi Komisi Yudisial (Pusat), Komisi Yudisial Provinsi dan Komisi Yudisial Kabupaten/Kota sesuai dengan kewenangan masing-masing. Permasalahan yang dikaji dalam penelitian ini mengenai bagaimana model pengawasan hakim dalam mewujudkan penyelenggaraan kekuasaan kehakiman yang merdeka di Indonesia pada masa yang akan datang. Penelitian ini merupakan penelitian yuridis normatif dengan pendekatan undang-undang (statute approach) dan pendekatan konseptual (conceptual approach). Berdasarkan hasil penelitian, Komisi Yudisial Daerah memiliki tugas dan berwenang: pertama, melakukan pemantauan dan pengawasan terhadap perilaku Hakim; kedua, menerima laporan dari masyarakat berkaitan dengan pelanggaran Kode Etik dan/atau Pedoman Perilaku Hakim; ketiga, melakukan verifikasi, klarifikasi, dan investigasi terhadap laporan dugaan pelanggaran Kode Etik dan/atau Pedoman Perilaku Hakim secara tertutup; keempat, mengambil langkah hukum dan/atau langkah lain terhadap orang perseorangan, kelompok orang, atau badan hukum yang merendahkan kehormatan dan keluhuran martabat Hakim.
\end{abstract}

Kata Kunci: Komisi Yudisial, kekuasaan kehakiman, pengawasan

\section{Introduction}

The implemetion of judicial power cannot be separated from the influence of government and other authorities including the power of money. This has triggered thoughts which assume that it is necessary for an institution to ensure judicial power to comply with law which is justice for all. ${ }^{1}$ Judiciary credibility does not

$\Omega$ This is the result of research based on Letter of Assignment for Fundamental Research Number 2095/UN23.14/ PN/2015, on March 2 ${ }^{\text {nd }}$, 2015.

1 Muhammad Fauzan, “Eksistensi Komisi Yudisial Dalam Struktur Ketatanegaraan Republik Indonesia dan yang necessarily appear alone; however, it passes several verifications which show that judiciary and judges truly uphold the law and truth, and that justice is absolute and consistent. The people trust and justice seeker enable the judge in the court to finish the case through legal action well. Therefore, when judges assert their authorities, supervision is needed. In order to ful-

Seharusnya diatur dalam Peraturan-perundang", Jurnal Dinamika Hukum, Vol. 8 No. 1, January 2008, Purwokerto: Faculty of Law Universitas Jenderal Soedirman, page 44. 
fill the need of judges supervision, a state institution is needed to be given the power in positive constitutional law, one of which is Judicial Commission (JC).

Judicial Commission which is under the same roof as the Supreme Court aims to avoid judicial tyranny. By the supervision conducted by Judicial Comission which is independent, it is highly expected that the Judicial Commission is able to monitor judicial power which involves elements of society at its widest and not only monitor them internally. ${ }^{2}$ Frequently, there was a misperception in Judicial Commission when conducting its function as supervisor for judges behavior. Nonetheless, it was ended by the ratification of Law Number 18 Year 2011 on Law Alteration based on the Law Number 22 Year 2005 on Judicial Commission which undergo extention for stronger Judicial Commission. ${ }^{3}$

Judicial Commission in performing its duty of supervision toward judges' behavior as stated in Article 20 section (1) of Law Number 18 Year 2011, ought to pay attention on: first, obeying the legislation; second, upholding Ethic Code and/or Judges Code of Conduct; third, keeping statement or information attained confidentially due to its confidentiality based on its position as member, and fourth, mantaining independency and Judges' freedom in investigating, judging and deciding the case. Nevertheless, in conducting supervision to judges behavior, Judicial Commission does not only have to pay attention on Law Number 18 Year 2001 on Law Alteration of Law Number 22 Year 2004 on Judicial Commission, but also to Law on judicial power in Law Number 3 Year 2009 and on Second Law Alteration under the Law Number 14 Year 1985 on Supreme Court and Law Num-ber 48 Year 2009 on Judicial Power.

2 Verdinandus Kiki Afandi, Nengah Suantra, Made Nurmawati, "Pengawasan Komisi Yudisial Terhadap Kehormatan Keluhuran Dan Martabat Perilaku Hakim Berdasarkan UUD Negara Republik Indonesia 1945”, Jurnal Kertha Semeaya, Vol. 01, No. 1, January 2013, Denpasar: Law Science Study Program, Faculty of Law Universitas Udayana, page 3 .

3 Muhammad Fauzan, "Pasang Surut Hubungan Antara Mahkamah Agung Dengan Komisi Yudisial Dalam Sistem Ketatanegaraan Republik Indonesia”, Jurnal Dinamika Hukum, Vol 12 No. 1, 2012, Purwokerto: Faculty of Law Universitas Jenderal Soedirman, page 127.
In accordance with Article 32A of Law Number 3 Year 2009 on Supreme Court, it is stated that Supreme Court is an internal supervision institution for judge's behavior, and an external supervision of judge's behavior shall be made by the Judicial Commission. The implementation of internal and external supervision must comply with the ethic code and judge's code of conduct which are determined by Judicial Commission and Supreme Court. Furthermore, Law Number 48 Year 2009 on Judicial Power related to supervision of judges behavior is prescribed in Article 39 section (3) that "Internal supervision of judges behavior is conducted by Supreme Court", and Article 40 section (2) that prescribes: "In order to preserve and uphold the honor, dignity, and judges behavior, external supervision must be performed by Judicial Commision."

Based on the explanation above, it can be concluded that in order to preserve the dignity of judges; therefore, the supervision of judges behavior is performed by two state institutions. They are Supreme Court as the internal supervisor and Judicial Commision as the external supervisor. However, in the implementation, society mostly report to the supervisor institution if any judges misconduct is found.

\section{Problem}

Based on the background above, the study examines how the model of judge supervision realizes the implementation of independent judicial power for the future Indonesia.

\section{Research Method}

This study is normative juridical research. The approaches used in this study are statute approach and conceptual approach. ${ }^{4}$ Statute approach is used to know and understand the law related to the supervision of judges in Indonesia, meanwhile conceptual approach is used to find the basic idea and the concept of judge supervision. This conceptual approach is important to reconceptualize the model of judge supervision in Indonesia.

4 Peter Mahmud Marzuki, 2005, Penelitian Hukum, Jakarta: Kencana, page 93. 


\section{Discussion}

The controversy over whether supervision of judge behavior is needed or not has been an old issue. There is a concern that if the judges are supervised, it will violate the accepted universal principles. Judicial power is independent, cannot be influenced by other power including government.

As a result of constitutional development and the higher demand of modern society, the concern of the misuse of judicial power exercised by judge is often interpreted as a representative of God in the world. Therefore, it will be reasonable if the idea and concept for supervising judge behavior becomes urgent. The public trust to judicial affair especially judges has reached to the lowest level; therefore, there is a satire acronymed which is aimed to the judicial affair like the term hakim (judge) is often spoofed for Menai "hubungi aku kalau ingin menang!" ("contact me if you want to win!").

Judges have crucial position with all of his authorities, for instance, a judge is able to transfer someone's ownership right, repeal citizen's freedom, declare invalid arbitrary action by government against the society, or even remove someone's right to life. ${ }^{5}$ As a judge with substantial authority, law and justice enforcement must be free from the influence of other authorities, including government, money and other political things.

The authority of judges is very substantial. It demands high responsibility because every said verdict containing irah-irah (a Javanese vow) "For the Sake of Justice under the One Almighty God" which implies that the obligation to uphold truth and justice shall be accounted horizontally to humans and vertically to God Almighty. ${ }^{6}$ Although judges have substantial authority in making verdict of the disputants' case, they have to be highly responsible and rea-

Dudu Duswara Machmudin, "Peranan Keyakinan Hakim dalam Memutus suatu Perkara di Pengadilan", Varia Peradilan, No. 252, October 2006, Jakarta: IKAHI, page 51.

6 Ketua Mahkamah Agung RI, "Pedoman Perilaku Hakim", Varia Peradilan, No. 252 October 2006, Jakarta: IKAHI, pages 5-31 lize what his responsibility is. ${ }^{7}$ Judges have an important position as executor of judicial power; therefore, in order to keep the prestige and image of the judiciary, the role of supervision and guidance toward the corps of judges is very important. ${ }^{8}$ To avoid the misuse of power or authority of judges, the existence of an institution which has been authorized to supervise judges in creating and implementing the authority of judges to uphold the law and justice is highly needed within some limitations that can guarantee the independence and freedom of judges in examining and deciding cases.

The independent judicial power which exists in the freedom for judges in judging cases is risky. The possibility of abusing power and act arbitrarily in the name of judges freedom is high. Thus, according to Bagir Manan, the limitations are needed to avoid power abuse without forfeiting the freedom principle as it is the nature of power. Those limitations are: ${ }^{9}$ first, Judges decide cases in accordance with law; second, Judges decide cases solely for justice; third, in interpreting construction or legal discovery, judges must stick firmly to general principle of law and the general principles of nature justice; and fourth, a possible mechanism must be arranged for taking action against judges who act arbitrarily and abuse the power. Related to the fourth limitation, Bagir Manan explains that the action itself is not about juridical function. There is no power which is able to take action against judges regarding the unfair decision. The action toward judges is only personal attitude which can give detrimental effect to the country or lower the dignity of judicial power. ${ }^{10}$

The effort to create and to enforce the rule of law and justice is not initiated by the

7 Suhrawardi K. Lubis Dalam Firman Floranta Adonara, "Prinsip Kebebasan Hakim Dalam Memutus Perkara Sebagai Amanat Konstitusi”, Jurnal Konstitusi, Vol. 12 No. 2, June 2015, Jakarta: Constitutional Court, page 6.

8 Widiyatno Sastrohardjono, "Profesionalisme Dan SDM Hakim Sebagai Salah Satu Prasyarat Peradilan Yang Agung (Court Excelent)", Varia Peradilan, No. 331, June 2013, Jakarta: IKAHI, page 13.

9 Bagir Manan, 1995, Kekuasaan Kehakiman Republik Indonesia, Bandung: LPPM of Universitas Islam Bandung, pages 12-13.

10 Ibid. 
existence of Judicial Commission after Indonesia Constitution 1945 Amendment, but it has been sought since 1968. The idea to supervise the judges behavior is regulated in Law Number 35 Year 1999 on Alteration of Law Number 14 Year 1970 on Principal Provisions of Judicial Power in which the explanation informs the existence of Judge Honor Council (JHC). JHC has the authority to supervise judges behavior, give recommendation for recruitment, promote and mutate the judges, and establish ethic code for judges.

Supervision of judges behaviour develops well because of the existence of Indonesia Constution 1945 Amendment. As mandated in Article 24B Indonesia Constitution 1945 Amendment, it specifies that: first, Judicial Comission is independent which has the authority on the appointment of Supreme Court Judges and other authorities in order to mantain and en-force the honor, dignity, and judges behaviour; second, Juridical Commission members must have knowledge and experience in law as well as high integrity and impeccable personality; third, Judicial Commission members are appointed and dismissed by President by House of Representatives consent; and fourth, structure, position, and membership of Judicial Commission are regulated in law.

According to that law, the terminology of "supervise" from Judicial Commission, means only to maintain and enforce the honor, dignity and judges behavior. The sentence of maintain and enforce the honor, dignity and judges behavior is interpreted with the sentence of supervise judges behavior in Law Number 22 Year 2003 and Law Number 18 Year 2011 on Law Alteration Number 22 Year 2003 on Judicial Commission.

Based on Article 24B section (4) Indonesia Constitution 1945 Amendment, Law Number 22 Year 2004 on Juridical Commission was formed which firmly gives authority to supervise judge behavior. As mandated in part of consideration letter $b$, it specifies that:

Judicial Commission plays an important role in the effort of making the independent judicial power through candidacy of
Supreme Court Judges also transparent and participative supervision of judges in order to enforce the honor, dignity and judges behavior.

Then, it is reaffirmed in Article 20 which specifies that:

In doing its authority as mentioned in Article 13 letter b, Judicial Commission functions to supervise judges behavior in order to enforce the honor, dignity and judges behavior.

The terminology of supervision of judges behavior encouraged the issue of Constitutional Court Decision Number 005/PUU-IV/2006, in which in that decision, Constitutional Court limits the definition of judge and the object of supervision which is conducted by Judicial Commission. Based on the decision, the author-ity of Judicial Commission has been reduced; nevertheless, the existence of $\mathrm{JC}$ gains stronger legitimacy as a mandated institution by Indonesia Constitution 1945.

The issue of Constitutional Court decision is regarded as an implementation of letter of judges supervision behavior; however, slow but sure, the enforcement of Judicial Commission in doing the authority to maintain and enforce honor, dignity and judges behavior starts to reclaim the pride as external supervisor institution as it is formed the three laws which are Law in General Judiciary, Law in Religion Judiciary, and Law in The State of Administrative Court, also Law Number 18 Year 2011 on Law Alteration Number 22 Year 2004 on Judicial Commission.

One of the important points in Law of General Judiciary, Law of Religion Judiciary and Law of The State of Administrative Court is a regulation on the formation of Judge Honor Legislator (JHL) established by Supreme Court and Judicial Commission that have authority to give penalty to judges. Therefore, Judicial Commission, as external supervision institution, establishes the objectives of supervision as mandated on Article 13A section (2) that determine: as supervision in section (1), to maintain and uphold honor, dignity, and judges behavior, external 
supervision of judges behavior performed by Judicial commission.

Several points to be noted in implementing the supervision functions in order to maintain and uphold honor, dignity and judges behavior are: first, Judicial Commission establishes coordination with Supreme Court; second, Judicial Commission establishes coordination with Supreme Court; third, In case of different outcome of supervision from internal institution supervised by Supreme Court and different outcome of supervision from external institution supervised by Judicial Commission, the supervision will be conducted by Supreme Court and Judicial Commission; fourth, Judicial Commission has duty in supervising judges behavior based on ethic code and judges code of conduct.

Judicial Commission in implementing its duties and functions as external supervision institution, conducts some points: first, accept and extend the complaint of society and/or the infraction supposition for Ethic Code and Judges Code of Conduct; second, examine and determine the infraction supposition for Ethic Code ad Judges Code of Conduct; third, able to attend the court; fourth, accept and extend the supposition from Supreme Court and judiciary institutions under the Supreme Court for the infraction supposition of Ethic Code and Judges Code of Conduct. fifth, verify the complaint from society and/or the infraction supposition for Ethic Code and Judges Code of Conduct. Sixth, Seek for information and data to Supreme Court and/or Court; seventh, call and seek for information from the judges that is being suspected do the infraction of Ethic Code and Judges Code of Conduct for supervison data; and/or eighth, determine the decision based on infraction supervision data for Ethic Code and Judges Code of Conduct. ${ }^{11}$

The authority implementation in maintaining and upholding honor, dignity and judges behavior becomes clearer after Constitutional Court Decision No. 005/PUU-IV/2006 that refers to Law Number 18 Year 2011 concerning Law Alteration Number 22 Year 2003 on Judicial Com-

\footnotetext{
11 Ibid.
}

mission is issued. It can be concluded from Article 20 and Article 20A Law Number 18 Year 2011 that broadly determine that in order to maintain and uphold honor, dignity and judges behavior, Judicial Commission has some duties as follows: first, examining and supervising judges behavior; second, accepting the com-plaint from society for the infraction of Ethic Code and Judges Code of Conduct; third, in-ternally verifying, clarifying, and investigating the infraction supposition for Ethic Code and Judges Code of Conduct; fourth, determining the accuracy from the infraction supposition for Ethic Code and Judges Code of Conduct; fifth, determining a legal move or another move to individual, group, or legal institution that humiliate Ethic Code and Judges Code of Conduct; sixth, attempting the improvement of capacity and the walfare of judges; seventh, asking for help to law enforcement officer to wiretappe and record the court where the infraction supposition for Ethic Code and Judges Code of Conduct is directed to the judges.

Judicial Commision in implementing the duties to maintain and uphold honor, dignity, and judges behavior refers to Law Number 18 Year 2011 that regulates the duties that should be implemented and considered by Judicial Commission: first, follow the Law of Legislation; second, enforce Etchic Code and Judges Code of Conduct; third, keep the data and information confidentiality because they are secrecy of Judicial Commission obtained by its position as the member; fourth, keep the independence of Judges in examining, judging, and deciding cases.

Judicial Commision in implementing the main duties and functions mandated in Indonesia Constitution is based on Article 24B section (4) Indonesia Constitution 1945 Amendment regulating that arrangement, position and affiliation of Judicial Commission is under the law. Based on the explanation above, in implementing the main duties, Judicial Commission must be based on the Law Number 22 Year 2004 j.o. Law Number 18 Year 2011.

Article 3 Law Number 22 Year 2004 stipulates that the location of Judicial Commission is 
in capital city, with the number of comisssioners according to Article 6 section (1) consisting of 7 persons. Hence, it can be assumed that Judicial Commission will not be able to do their main duties and functions to maintain and uphold the honor, dignity, and judges behavior as mandated in Article 24B section (1) Indonesia Constitution 1945 Amendment.

The number of Judicial Comission comissioners and the judges who will be supervised show unequal ratio. Similarly area of the country where judges spread all over the country will impact on the efectiveness of supervision. According to Supreme Court's Annual Report, in 2013 the number of district court judges until supreme court judges thereabouts 7.708 (seven thousand and seven hundred eight) judges.

Based on the data, it can be concluded that the ratio between comissioner of Judicial Commission and judges that will be supervised is 1 (one) comissioner of Judicial Commission has to supervise the behavior of 110 judges who spread all over the country. To optimize authority implementation in supervising judges behavior that is unequal with the number of Comissioners of Judicial Commission, Article $3 \mathrm{sec}$ tions (2) and (3) Law Number 18 Year 2011 grants the authority to Judicial Commission to recruit representatives.

In order to fulfill those stipulations, Judicial Commission issued Regulation Number 01 Year 2012 on Formation, Structure and Working Procedure of Judicial Commission in region, in which Article 2 stipulates that: firstly, in carrying out its duties, Judicial Commission can select their representatives in region; secondly, the selection aims to facilitate people in submitting report, increase the effectiveness of court monitoring, and the institutional socialization in order to maintain and uphold the honor, dignity, and judges behavior; thirdly, the formation of Judicial Commission representat-ives is assigned by the decision of Judicial Commission Chief after getting approval in plenary Judicial Commission members; forthly, the formation of representatives is based on the considerations which concern on the handling public complaints, complexity of court cases, avail- ability of resources and network in region, also the working effectiveness and efficiency.

Based on the Law Number 18 Year 2011, Judicial Commission can pick the representatives in region in accordance with its necessity. According to Judicial Commission Regulation Number 1 Year 2012 on the fromation, structure and working procedure of Judicial Comission in region, the formation of their representatives aims to make citizen easier in submitting report, increase the effectiveness of court monitoring, and the institutional socialization in order to maintain and uphold honor, dignity, and judges behavior. Since 2013, Judicial Commission form representatives in several regions, they are: Representatives in North Sumatera, Riau, South Sumatra, Central Java, East Java, East Kalimantan, West Kalimantan, South Sulawesi, North Sulawesi, West Nusa Tenggara, East Nusa Tenggara, and Maluku.

The existence of 34 Judicial Commission representatives which are convenient with the number of provinces and their location which is in the capital of the province have overcome the problem of limited commissioners. Besides, they help obtain the data and information about judges behavior in region which is based on Article 5 Judicial Commission Regulation Number 2 Year 2012. The regulation contains: firstly, receive public reports about infraction supposition of Ethic Code and Judges Code of Conduct and then report them to Judicial Commission; secon$d l y$, engage the assembly monitoring in each representative egion; thirdly, engage Ethic Code and Judges Code of Conduct socializ-ation, Judicial Commission institution role socialization, the socialization of information about judges and Supreme Court Judges candidate selection, also other socializations as prevention of judges behavior violation; forthly, perform other duties given by Judicial Commission.

Based on several stipulations above, representatives in supervising judges behavior functions as an agent. The agent which facilitates citizen in submitting a report, increase the effectiveness of assembly supervision and the institution socialization in order to maintain and uphold the honor, dignity also judges behavior. 
Therefore, the position of representatives who spread in 34 provinces is not more than 'post office' whose duty delivers every report and information from citizen about infraction supposition of ethic code and judges code of conduct to Judicial Commission. Meanwhile, the follow-up of those reports is none of representatives duty.

It is important to note that the existence of representatives can still ensure the court independency. There is concern that the involvement of representatives in form of "networking" in Judicial Commission which is not an entity under Judicial Commission in supervising judges in court will impact the independency of judges at the court. ${ }^{12}$ Putting aside the fact that representatives do not have authority like Judicial Commission Commissioners; nonetheless, in doing their job shows that the representatives are able to be an agent to provide information related to report from the people on presumption of Ethic Code and Judges Code of Conduct. Since 2005 until April 2014, there are at least 10.455 reports, both registered and unregistered including online report.

The existence of representatives does not only facilitate people who experience disadvantages or disagree with the judges behavior but also to report to Judicial Commission through representatives existed in each region. The existence of representatives based on Judi-cial Commission report also enhances the performance of Judicial Commission; it can be seen from several reported cases that have been addressed.

Based on Annual Report of Supreme Court in 2013, the number of public reports related to the violation of Ethic Code and Judges Code of Conduct which can be taken for further action from 2005 until April 2014, from the total of 1918 reports, 377 reports have been taken for further action to the assessment from the judges, 451 reports have been taken further action until examination of complainant/witness, while other reports which have been taken for fur-

12 Bismar M. Gultom, "Hormati Independensi Badan Peradilan”, Varia Peradilan, No. 350, January 2015, Jakarta: IKAHI, page 65. ther action with request letter of verification and continue to other institutions for further action are 1027 reports. Furthermore, 63 reports which have been taken for further action until the request of evidence, investigation and continue to Supreme Court. In addition, number of public report accepted by Judicial Commission in the period of January until April 29th, 2016 is 488 reports and 572 of copy reports.

Based on the data above, it can be concluded within four months, the average number of reports related to judges behavior are 122 reports for each month or 4 reports each day received by Judicial Commission. Then, looking from the total amount of received reports and copy which is 1060; if the average amount of report that Judicial Commission receives in a month and copy reports is 265 ; thus, the total is nine reports and copy reports every day.

However, based on the type of cases reported to Judicial Commission in the period of January until April 29 $9^{\text {th }}$, 2016, there were 488 reports and 572 copy reports received by Judicial Commission. Concerning to the data above, it can be said that the existence of Judicial Commission Team Work of Representative has indeed provided help in assisting Judicial Commission to do its main duty and function.

Looking at the explanation above, it is necessary to discuss the representative improvement in the future which is as Judicial Commission Commissioners, or in other words, the number of commission needs to be added. Ideally, each province must have one commissioner with 3 assistants and each district/city must have one commissioner completed with secretarial elements. The number of province today is 34 with the total of Districts/Cities 514 which involve 508 Districts/Cities as autonomous area, and 5 district/cities as administrative are in Jakarta. Concerning those facts, the researcher believes that in the future, the number of commissioners will be 555 with details; 7 Judicial Commission commissioners, 34 commissioners for Province Judicial Commis-sion, 514 commissioners for District/City Judicial Commission with each work area and jurisdiction. With the amount of 555 commissioners, it will 
improve the comparison ratio between judges being supervised and commissioner. If the number of judges as previously has been stated is still the same which is 7.708 judges, then 1 commissioner will have to supervise 9 judges.

Regarding the cases above, the researcher considers that the enforcement of supervision function toward the judges behavior by
Judicial Commission will work effectively, and in time honor, dignity and judges behavior can be maintained. Then, it will encourage the establishment of independent judicial power and able to enforce the law and justice. Therefore, the model of judges supervision in the future can be illustrated in the following chart.

\section{Illustration 1}

Model of Judges Supervision in the Future

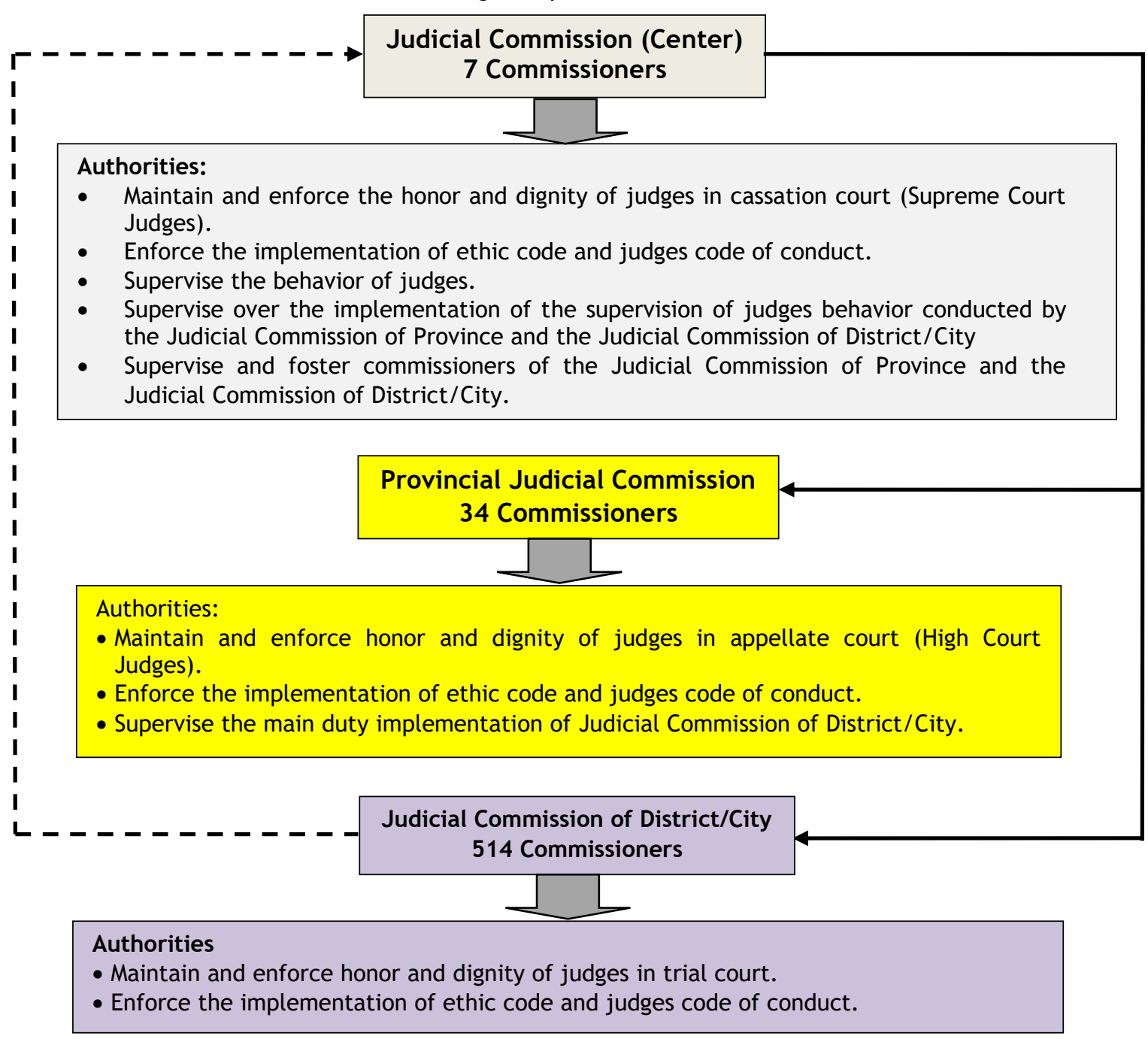

\section{Conclusion}

Model of judges supervision in Constitutional system in the future will only be supervised by Judicial Commission as the external supervisor which encompasses the Judicial Commission (Center), Provincial Judicial Commission and District/ City Judicial Commission corres- ponding to each authorities with number of 555 commissioners consisting of 7 (seven) commissioners in Judicial Commission (Center), 34 commissioners in Provincial Judicial Commission, and 514 commissioners in Judicial Commission of District/City. Judicial Commission has other authorities as being regulated in Article 24B 
of Indonesia Constitution 1945 Amendment, which are: firstly, to propose the appointment of Supreme Court Judges and has another authority to maintain and enforce honor, dignity and judges behavior; secondly, to supervise merely the Supreme Court judges behavior; third$l y$, to supervise the implementation of Judges behavior supervision performed by Provincial Judicial Commission and Judicial Commission of District/City; fourthly, to supervise and foster commissioner of Provincial Judicial Commission and Judicial Commission of District/City. In the meantime, Regional Judicial Commission has authorities to: firstly, to monitor and supervise the judges behavior; secondly, to receive file from the public which is intertwined with violation of ethic code and judges code of conduct according to the working field; however, Provincial Judicial Commission also has duty to supervise the implementation of main duty and function of Judicial Commission of District/City; thirdly, to verify, clarify, and investigate the file report of alleged violation of ethical code and judges code of conduct privately according to the working field; fourthly, to take legal action and/or other steps against the individuals, groups, or legal institutions which are degrading the honor and dignity of Judges.

\section{Suggestion}

To optimize the implementation of main duty and function of Judicial Commission as well as to realize the harmony among supervision of judge institutions, the following suggestions are proposed: firstly, a clear definition regarding the definition of supervision of judges behavior is needed to avoid suspicion that the implementation of supervision will violate the principle of independent judiciary also the independence and freedom of judges; secondly, reformulation regarding to the provision in Article 24B section (1) of Indonesia Constitution 1945 Amendment is required, particularly associated to the phrase "other authorities in order to maintain and enforce the honor, dignity and judges behavior."

\section{References}

Adonara, Firman Floranta. "Prinsip Kebebasan Hakim Dalam Memutus Perkara Sebagai Amanat Konstitusi". Jurnal Konstitusi. Vol. 12 No. 2 June 2015. Jakarta: Constitutional Court;

Afandi, Verdinandus Kiki. Et.al. "Pengawasan Komisi Yudisial Terhadap Kehormatan Keluhuran Dan Martabat Perilaku Hakim Berdasarkan Uud Negara Republik Indonesia 1945". Jurnal Kertha Semaya. Vol. 1 No. 1. January 2015. Denpasar: Faculty of Law Universitas Udayana;

Fauzan, Muhammad. "Eksistensi Komisi Yudisial Dalam Struktur Ketatanegaraan Republik Indonesia dan yang Seharusnya diatur dalam Peraturan-perundang". Jurnal Dinamika Hukum. Vol. 8 No. 1 January 2008. Purwokerto: Faculty of Law Universitas Jenderal Soedirman;

Fauzan, Muhammad. "Pasang Surut Hubungan Antara Mahkamah Agung Dengan Komisi Yudisial Dalam Sistem Ketatanegaraan Republik Indonesia". Jurnal Dinamika Hukum. Vol 12 No. 1. Purwokerto: Faculty of Law Universitas Jenderal Soedirman;

Gultom, Bismar M. "Hormati Independensi Badan Peradilan". Varia Peradilan No. 350. January 2015. Jakarta: Supreme Court of the Republic of Indonesia;

Ketua Mahkamah Agung RI. "Pedoman Perilaku Hakim". Varia Peradilan. No. 252. October 2006. Jakarta: Supreme Court of the Republic of Indonesia;

Machmudin, Dudu Duswara. "Peranan Keyakinan Hakim dalam Memutus suatu Perkara di Pengadilan". Varia Peradilan. No. 252. October 2006. Jakarta: Supreme Court of the Republic of Indonesia;

Manan, Bagir. 1995. Kekuasaan Kehakiman Republik Indonesia. Bandung: LPPM of Universitas Islam Bandung;

Marzuki, Peter Mahmud. 2005. Penelitian Hukum. Jakarta: Kencana;

Sastrohardjono, Widiyatno. "Profesionalisme dan SDM Hakim Sebagai Salah Satu Prasyarat Peradilan Yang Agung (Court Excelent)". Varia Peradilan. No. 331. June 2013. Jakarta: Supreme Court of the Republic of Indonesia. 